\title{
Research Items
}

Cultural Analysis in Western Europe. When Prof. H. J. Fleure touches upon a familiar topic in his occasional lectures, he may be trusted to approach it at a new, or at least unfamiliar, angle. The lectures which he has delivered at the John Rylands Library, Manchester, in the last three years afford apposite examples. The latest, recently published in the Bulletin of the Library, deals with the megalithic problem, and is, in his own words, an attempt to show "that the megaliths are not a matter of a vanished people and a forgotten civilisation; they belong to the core of our heritage as Western Europeans" ("Prehistoric Elements in our Heritage." By Prof. H. J. Fleure. Pp. 36. Manchester : Manchester University Press, and John Rylands Library, 1934. Is. 6d. net). He argues with an almost bewildering wealth of detail that the civic civilisation, which developed in early prehistoric times in the Near East, expanded by land and sea to form a series of archæological provinces in distant lands, to which adventurers took something of the religious associations of a common life. In attacking the problem of the megalith, Prof. Fleure has taken the position that buildings, no longer the civic type of orderly shaped stone, but of rough stone, including the megaliths, appear in different regions and at different dates. In other words, it was the concept and not the form which was carried from province to province. These provinces, in which development took place along different lines and with varying stimuli, were none of them isolated; each linked up with others in more than one direction. Among the examples of the persistence of the influence of the megalith and the culture of which it was a manifestation down to Christian times and later, Prof. Fleure cites, inter alia, the occurrence of cults from early prehistoric times at places of entry such as that of St. Iago in Galicia and Portugal and that of the saint of St. David's in South Wales.

Brahmins of Behar. A comparative study of the physical characters of two classes of the Brahmins of Behar has been made by Bajra Kumar Chatterjee (Anthropological Bulletins from the Zoological Survey of India, No. 2). Of the six most important groups of Brahmins of Behar, the present study deals with two, the Kanaujia and the Maithil. The Kanaujia hold a very high position among the Brahmins of northern India. Both this group and the Maithil belong to the five divisions known as the Panch Gaur. Among the Kanaujia are many exogamous sub-sections having different status for matrimonial purposes, while among the Maithil there are numerous exogamous groups which constitute a complete hypergamous system. A hundred individuals from each of the two groups were meas. ured. Seventeen characters are recorded and thirteen indices calculated, in addition to observations of skin, eyes and hair. A comparison of the two series of measurements shows that the two groups are physically alike in most of the characters, and can with good reason be assigned to the same racial stock. Differences noted in a few characters are probably due to the presence of another strain. A high percentage of certain characters, such as is shown by the breadth-height index and the nasal index, points to miscegenation with some such aboriginal stock as the Bhils or Chenchus. This appears to have proceeded further among the Maithil than in the Kanaujia Brahmins. A further comparison with measurements taken by other observers elsewhere points to the fact that these two groups of Brahmins are related to some of the groups of Bengal, Orissa and southern India. Racial kinship is also discernible with the Namburdiri of Malabar; but there does not appear to be any with the Brahmins of the United Provinces of Agra and Oudh and Central India, this last conclusion being contrary to tradition, which, however, supports the connexion with the Brahmins of Orissa.

Vanadium in Marine Animals and in Mineral Oils. Vanadium has been known to occur in small quantities (of the order of about $10^{-5}$ per cent) in various terrestrial and marine animals and plants. In two groups of marine animals, namely, Ascidians and Holothurians, it has been found, however, in very high concentrations (up to 1.5 per cent of the ash in some Ascidians). This lends support to the theory according to which Tunicata and Echinodermata are considered of close phylogenetic affinity. Since sea-water contains very small quantities of vanadium, it appears probable that the source of the vanadium found in Ascidians is marine bottom muds, which are often rich in that element. Moreover, Ascidians form highly specialised biocoenoses on the sea-floor, and after their death they should enrich the bottom sediments with vanadium. It is suggested, therefore, by A. Vinogradov (C.R., Acad. Sci. Leningrad, 3, No. 6) that oils containing vanadium are connected in their origin with marine sediments formed under conditions favourable to organisms concentrating vanadium.

Burmese Fishes. A collection of fishes from the South Shan States and the Pegu Yomas, Burma, is described by Dr. Sunder Lal Hora and Dev Dev Mukerji (Rec. Indian Mus., 36, Part 1, March 1934). The material was obtained by Mr. V. P. Sondhi of the Geological Survey (both of the districts consisting of hilly tracts) from small torrential streams with a rocky bed. The streams are characterised by rapids and slow currents with pools and back-waters here and there. Some of them are diverted for the irrigating of 'paddy' fields, and in the South Shan States the water is usually charged with lime to such an extent that it forms travertine dams causing small falls. The fishes from Pegu Yomas were caught by putting a dam across a small stream and allowing the bed below the dam to run dry, and picking up the fish from underneath stones and boulders and from crevices. An abnormal specimen of Ophiocephalus gachua, a widely distributed and very variable species of the Oriental region with a marked amphibious life, had no ventral fins, but had the basipterygials only slightly deformed. This raises the question of the validity of the generic names Channa and Ophiocephalus, in Channa the ventral fins being totally absent. The authors are of the opinion, after examina. tion of a number of specimens, that Ophiocephalus harcourt-butleri, Annandale, is synonymous with O. gachua.

Trematodes from Deep-Water Fishes. Mr. H. W. Manter has described the digenetic trematodes col. lected from many species of fishes from 40 to 582 
fathoms, trawled at Tortugas, Florida (Papers from the Tortugas Laboratory of the Carnegie Institution of Washington, 28, 1934). The worms are in general markedly distinet from those in the nearby shallow water, and approximate more closely to the cooler water forms of more northerly regions. Seven species are identical with the northern forms, including the common Derogenes varicus, which is found in a large number of British fishes, and is very widely distributed. It has been recorded from more than 50 species, 5 more being added in the present work, occurring in depths ranging from 190 to 315 fathoms. Out of 49 trematodes recorded, 15 species belong to the Hemiuridæ, 13 to the Fellodistomidæ and 11 to the Bucephalidæ. Interesting results arising from this research show restrictions in distribution in depth. Thus, some trematodes are able to live in several different fishes, but appear to be limited to certain depths. Cymbephallus vulgaris is the commonest species collected, and was found in 15 species of deep-water fishes but never in those from shallow water. It was not found above 40 fathoms, and is most prevalent from 75 to 175 fathoms, not occurring at lower depths. Of the few species occurring both in shallow and deep water, Sterrhurus floridensis is very common. This is the only sexually mature form found generally in both shallow water and deep water regions.

Root Rots of the Strawberry. Dr. G. H. Berkeley and Miss Isabel Lauder-Thomson contribute an article on "Root Rots of Strawberry in Britain" to the Journal of Pomology and Horticultural Science, 12, No. 3, Oct. 1934. Dr. Berkeley is senior pathologist-in-charge at the Dominion Laboratory of Plant Pathology, St. Catharine's, Ontario, Canada, and lately stayed for a year at the East Malling Research Station, Kent. The 'black lesion' type of strawberry root rot causes severe damage to the crop in Canada, and the present paper shows that it is a serious factor in strawberry degeneration in Great Britain. Five species of soil fungi have been proved capable of attacking the roots of strawberries, often causing death. They are Coniothyrium Fuckelii, Hainesia lythri, Cylindrocarpon radicicola, Fusarium orthoceras, and Pachybasium candidum. Symptoms do not seem to vary greatly with different fungi, and infected plants are always dwarfed and brown, whilst the roots have black lesions and little fibre. Many dead roots appear, and severely infected plants often wilt and die. Crop rotation and the selection of healthy runners are the main control methods (see also Nature, 132, 570, Oct. 7, 1933).

Irish Fungi New to the British Isles. Messrs. A. E. Muskett, H. Cairns and E. N. Carrothers are making a study of the fungus flora of Ulster, and publish fresh annotated records from time to time. Their latest contribution reports the addition of 275 species and 9 varieties ("Further Contributions to the Fungus Flora of Ulster", Proc. Roy. Irish Acad., 42, Section B, No. 4, Sept. 1934). No less than 133 species and 8 varieties are new Irish records, whilst two species and one variety are new British records. Hygrophorus agathosmus, Fr., var. aureofloccosus, Bres. was found by Mr. Carleton Rea at Glenariff in 1931. Corticium anceps was found at Hallsborough and was parasitic on bracken, but did not appear to do much damage to its host. Phytophthora megasperma was isolated by Cairns from potato tubers affected with pink rot. It has hitherto been described only from the United States, where it causes a disease of hollyhocks. The new fungus can cause a pink rot of potato tubers indistinguishable from that produced by the usual parasite, $P$. erythroseptica. The records include considerable numbers of Phycomycetes and Fungi Imperfecti, in addition to the larger forms.

Turbulence near the Ground. A lecture on this subject was delivered before the Royal Aeronautical Society on November 22, by Prof. W. Schmidt, director of the Austrian Meteorological Service. The lecture was mainly devoted to the discussion of some 350,000 observations of wind in the lowest 10 metres of the atmosphere. The instrument used consisted of a light wire ring of $20 \mathrm{~cm}$. diameter, covered with muslin, and mounted on a horizontal axis $50 \mathrm{~cm}$. from the centre of the ring. In practice, a number of the rings were fixed on a frame set vertically at right angles to the wind direction, the dimensions of the frame being usually $6 \mathrm{~m} . \times 12 \mathrm{~m}$., so that the distribution of wind could be investigated instantaneously over a front of $12 \mathrm{~m}$. across wind and up to a height of $6 \mathrm{~m}$. above the ground, by photo. graphing the frame. Diagrams were shown representing the variation of wind over the area covered by the frame, and the variation of wind with time at different heights above the ground. Over a field of turnips the wind was more turbulent than over a stubble field in the lowest metre above the ground, but was less turbulent at heights greater than 1 metre. Some of the diagrams indicated that the occurrence of high velocities near the ground is to be explained by the intrusion of fast moving air from higher levels. This confirms the results described by Scrase in M.O. Geophysical Memoir No. 52. Tables of coefficients of correlation between the simultaneous observations of wind at points separated by vertical distances up to $5 \mathrm{~m}$. and horizontal distances up to $10 \mathrm{~m}$., showed that the distance at which the coefficient falls off to any particular value increases with height, as might be expected if the dimensions of the eddies increase with height above the ground. The correlations were all smaller with strong than with light winds. This was attributed by Schmidt to the large number of frictional eddies produced in strong winds. The values of the Austausch coefficient (eddy diffusivity $\times$ density) were shown in a table, the values varying from $0 \cdot 8$ to $5,800 \mathrm{~cm}^{-1}$ gm. sec. ${ }^{-1}$, corresponding to a variation of the eddy diffusivity, $K$, from about 600 to about $4.6 \times 10^{6}$ cm. ${ }^{2}$ sec. ${ }^{-2}$ The very high value was associated with a wind from a lake with 500 metres of dry strand in front of the point of observation.

Crystal-Structure of Bismuth Oxyhalides. At the meeting of the Mineralogical Society of Great Britain on November 1, Mr. F. A. Bannister read a paper giving the results of X-ray study of crystals of $\mathrm{BiOCl}, \mathrm{BiOBr}$, and BiOI which he had succeeded in preparing by a diffusion method. They are formed as square plates rarely larger than $0.3 \times 0.3 \times 0.05$ $\mathrm{mm}$. showing flat pyramidal faces vicinal to the basal plane; all yielding a negative uniaxial figure under the microscope. Laue and rotation photographs show that the space-group of these compounds is $P 4 / n m m=\mathrm{D}_{4 h}^{7}$ and that their crystal-structures closely resemble that of matlockite ( $\mathrm{PbFCl}$ ), the main difference lying in the closer packing of the bismuth and oxygen ions than the packing of the lead and 
fluorine ions. The unit-cell sides and parameters of the atoms of the bismuth oxyhalides are:

$\begin{array}{lclcc} & a & c & u & v \\ \text { BiOCl } & 3 \cdot 89 & 7 \cdot 37 \mathrm{~A} . & 0 \cdot 171 & 0 \cdot 650 \\ \text { BiOBr } & 3 \cdot 92 & 8 \cdot 11 & 0 \cdot 153 & 0 \cdot 650 \\ \text { BiOI } & 4 \cdot 01 & 9 \cdot 14 & 0 \cdot 132 & 0 \cdot 667 \\ \text { PbFCl } & 4 \cdot 09 & 7 \cdot 21 & 0 \cdot 208 & 0 \cdot 650\end{array}$

The co-ordinates of the atoms in these structures are :-Metal, $00 u, \frac{1}{2} \frac{1}{2} \bar{u}$; halogen, $00 \mathrm{v}, \frac{1}{2} \frac{1}{2} \bar{v}$; oxygen, $\frac{1}{2} 00,0 \frac{1}{2} 0$. The calculated radius of the bismuth ion for all three oxyhalides is $1.0 \mathrm{~A}$. The interatomic distances within the halogen layers are less than the values usually accepted, especially for the oxyiodide.

Biological Effects of High-Energy Radiation. W. V. Mayneord (Proc. Roy. Soc., A, Oct. 15) considers the possible biological effects of high-frequency radiation of different energies. The radiation gives rise to fast-moving electrons by photoelectric absorption and by recoil (Compton scattering), and with 'hard' radiation the latter is the predominant process. The fast secondary electrons have a range in the tissue corresponding to many cells, but they lose little energy in passing through a single cell, while the slow electrons lose energy much more rapidly. If the biological changes in a cell are effected by the absorption of a small quantity of energy, 'hard' radiation, say, $\gamma$-rays, should be very effective relative to $X$-rays which produce short trails of intense ionisation, while if a large transfer of energy to a single cell is required to affect the latter, the soft rays will be relatively more efficient for equal amounts of absorbed energy. This provides a possible basis for the selective action observed by some workers in which the destruction of rapidly growing cells relative to ordinary cells was more marked with short wave radiation. The paper contains calculations of 'survival curves' of cells exposed to radiation, made on various assumptions about the electronic treatment necessary to kill a cell.

Experiments with Heavy Hydrogen. A. Farkas and L. Farkas have continued their interesting work with heavy hydrogen (Proc. Roy. Soc., A, Oct. 1) and they now suggest that the separation of the hydrogen isotopes by the electrolysis of water is due largely to the simple fact that the equilibrium

$$
\mathrm{HD}+\mathrm{H}_{2} \mathrm{O} \rightleftharpoons \mathrm{HOD}+\mathrm{H}_{2}
$$

corresponds to a gas phase which is about four times as rich in $\mathrm{D}$ as the liquid phase. The composition of the gas obtained by electrolysing various heavy-light water mixtures is similar to that obtained by bringing hydrogen into contact with the mixtures in the presence of a catalyst (palladium black). This reaction explains the fact that the separation factor is not very dependent on the conditions of electrolysis, but it is not the only factor operating since the factor may be higher than six in efficient fractionation experiments. In a second paper, the authors have described the use of the heavy isotope atoms as 'Iabelled' hydrogen atoms in experiments on the ethylene-hydrogen reaction, performed in presence of a nickel catalyst. The experiments show that an exchange reaction:

$$
\mathrm{HD}+\mathrm{C}_{2} \mathrm{H}_{4} \rightleftharpoons \mathrm{C}_{2} \mathrm{H}_{3} \mathrm{D}+\mathrm{H}_{2},
$$

takes place as well as the addition reaction :

$$
\mathrm{C}_{2} \mathrm{H}_{4}+\mathrm{HD} \rightleftharpoons \mathrm{C}_{2} \mathrm{H}_{5} \mathrm{D} \text {. }
$$

An experiment in which the state of the wire catalyst was followed by testing its efficiency in catalysing the conversion of para-hydrogen was also carried out and showed that at $20^{\circ} \mathrm{C}$. and $10 \mathrm{~mm}$. ethylene pressure the wire was nearly completely covered with ethylene.

Effect of Oxygen on Photoelectric Emissivity of Silver. At low temperatures, silver adsorbs oxygen rapidly, and the oxygen is readily removed by evacuation. At high temperatures the adsorption is slower and the oxygen is not removed except by prolonged heat. ing or by treatment with hydrogen. These two types of adsorption have been called 'physical' and 'activated', respectively, and it has been suggested that two types of forces are involved, in physical adsorption forces related to van der Waals' forces, and in activated adsorption those commonly termed electrostatic or valency forces. The theory of electrons in metals recently proposed by Sommerfeld provides a satisfactory picture of electrical forces present at surfaces, and since the photoelectric effect provides a sensitive means of study of the electrical properties of surfaces, A. K. Brewer (J.Amer. Chem. Soc., 56, $1909 ; 1934)$ has made an investigation on the adsorption of oxygen on silver on these lines. The photoelectric effect gives a measure of the work function associated with the removal of an electron from the metal surface. Very clean silver was used and the threshold values at $20^{\circ}$ and $600^{\circ}$ were found to correspond with the wave-lengths $2675 \mathrm{~A}$. and 2725 A., respectively. The following results were found: (1) At room temperature the presence of oxygen slightly enhances the emissivity, the effect disappearing with the removal of the oxygen. (2) After treating in oxygen, the silver was heated in a vacuum and then possessed an abnormally large emissive property, the effect disappearing only after long heating. (3) Heating in oxygen or exposure to ozone destroyed the emissivity. The effects observed under (1) and (2) were associated with 'physical' and 'activated' adsorption, respectively, whilst (3) is associated with the presence of 'surface' silver oxide. The lowering of the work function by 'physical' and 'activated' adsorption is brought about, apparently, by positive oxygen ions, whilst the increase in work function brought about by 'surface' silver oxide is apparently due to negative oxygen ions, since previous workers have shown that negative adsorbed ions raise the electron work function whilst positive ions shift it to lower values.

Enzymic Scission of the Nucleic Acid of Yeast. Following his work on the enzymic degradation of lecithin and lysocithin, Contardi, in conjunction with Ravazzoni, has published (Rendi. R. Ist. Lombardo, 67, Parts 11-15) an account of investigations on the enzymic scission of the nucleic acid of yeast. The results recorded show that the dim. inution occurring in the rotatory power of aqueous solutions of sodium nucleinate may be due, in some cases, to mutarotation phenomena. The rotation alone is, therefore, insufficient as a means of observing the hydrolysis of the nucleinate. The enzymic action of extracts of rice husk consists first in the almost complete demolition of the sodium nucleinate to simpler organic phosphorus compounds, this action being brought about by the phosphodiesterase at an optimum $p \mathrm{H}$ of 4 . Afterwards, the whole of the phosphorus is liberated in the form of inorganic compounds as a result of the action of the phosphomono-esterase, this proceeding best when the $p \mathrm{H}$ is $5 \cdot 5$. 